Research Article

\title{
Genetic and epigenetic effects of salinity on in vitro growth of barley
}

\author{
Aykut Demirkiran, Sevgi Marakli, Aslihan Temel and Nermin Gozukirmizi \\ Department of Molecular Biology and Genetics, Faculty of Science, Istanbul University, Vezneciler, \\ Istanbul, Turkey
}

\begin{abstract}
Morphological, physiological and molecular changes were investigated in in vitro salt-stressed barley (Hordeum vulgare L. cv. Tokak). Mature embryos were cultured in Murashige and Skoog medium containing 0 (control), 50 and $100 \mathrm{mM} \mathrm{NaCl}$ for 20 days. Both concentrations inhibited shoot growth, decreased fresh weight and protein content, and increased SOD (EC 1.15.1.1) activity in a dose-dependent manner. The lower concentration increased root growth. Salinity caused nucleotide variations in roots, but did not affect shoot DNAs. The higher concentration caused methylation changes, mainly hypermethylation in shoots. This is the first study on genetic and epigenetic effects of salinity in barley.

Keywords: Hordeum vulgare, Salt stress, Tissue culture, RAPD, CRED-RA.
\end{abstract}

Received: March 19, 2013; Accepted: September 2, 2013.

\section{Introduction}

The term salinity refers to the total dissolved concentration of major inorganic ions $\left(\mathrm{Na}, \mathrm{Ca}, \mathrm{Mg}, \mathrm{K}, \mathrm{HCO}_{3}, \mathrm{SO}_{4}\right.$, and $\mathrm{Cl}$ ) in irrigation, drainage and groundwaters. Certain ions, e.g. sodium $(\mathrm{Na})$, are toxic to plants when present in excessive concentrations (FAO, 1992), so germination and growth of most plant species are inhibited by salinity (Anuradha and Rao, 2001; Agarwal and Pandey, 2004; Kirmizi and Bell, 2012). Salt stress causes disruption of ionic equilibrium, inhibition of enzymatic activity, osmotic imbalance, membrane disorganization, inhibition of cell division and expansion, reduction in photosynthesis and production of reactive oxygen species (ROS) (Mahajan and Tuteja, 2005). ROS cause oxidative damage to nucleic acids, including modified bases, single or double strand breaks in DNA, and alter cytosine methylation (Weitzman et al., 1994; Imlay, 2003). Stress conditions alter cytosine methylation levels, independently of genetic variation (Lira-Medeiros et al., 2010). Rapid adaptation to unfavorable conditions is achieved by regulating gene expression through cytosine methylation (Lewis and Bird, 1991; Causevic et al., 2005; Lukens and Zhan, 2007). Stressinduced genetic (Liu et al., 2005; Guangyuan et al., 2007) and epigenetic (Guangyuan et al., 2007; Labra et al., 2002; Tan, 2010) variations were observed using molecular markers such as Random Amplified Polymorphic DNA (RAPD), Amplified Fragment Length Polymorphism (AFLP), Methylation Sensitive Amplified Polymorphism

Send correspondence to Aslihan Temel. Department of Molecular Biology and Genetics, Faculty of Science, Istanbul University, 34134 Vezneciler, Istanbul, Turkey. E-mail: atemel@ istanbul.edu.tr.
(MSAP) and Coupled Restriction Enzyme Digestion-Random Amplification (CRED-RA). Barley is a salt-tolerant crop (Ozturk et al., 2002) and has been thoroughly investigated for many aspects of salinity (Mian et al., 2011). Increase of lipid peroxidation, proline content, peroxidase, electrolyte leakage, activity of superoxide dismutase (SOD), ascorbate peroxidase, catalase and glutathione reductase, and decrease in relative water content and pigment content in barley were reported (El-Tayeb, 2005; Kim et al., 2005; Mian et al., 2011). Yet, to our best knowledge, there is no previous paper in the literature dealing with salinity, DNA damage and DNA methylation in barley. In this study, genetic and epigenetic variations were assessed in in vitro salt-stressed barley plants. For this purpose, we measured growth and SOD activity, the primary scavenger of ROS, and used RAPD and CRED-RA to investigate genetic and epigenetic variations, respectively, Random Amplified Polymorphic DNA (RAPD) to investigate genetic variations and DNA damage, and Coupled Restriction Enzyme Digestion-Random Amplification (CRED-RA) to investigate cytosine methylation changes. RAPD is a simple and fast technique for studying genetic diversity (Samal et al., 2012). CRED-RA (Methylation-Sensitive-RAPD) was developed to detect DNA methylation (Uthup et al., 2011). In this method, DNAs are divided into two groups and each group is digested with one of the HpaII/MspI isoschizomer pair restriction enzymes, after which the digestion products are amplified with random, 10-mer primers. Polymorphism between digestion products indicates the methylation pattern of the band. Both enzymes recognize the sequence 5'CCGG3', but HpaII cannot digest either of the methylated cytosines. MspI can digest DNA when the inner cyto- 
sine is methylated. Both enzymes can digest DNA when none of the cytosines are methylated. Salinity (50 and $100 \mathrm{mM}$ ) affected fresh weight, shoot and root length, and SOD activity. Banding patterns of root DNAs of NaCltreated plants were altered compared to control, while shoot DNAs of control and NaCl-treated plants revealed similar banding patterns. However, shoot DNAs exhibited a few changes in methylation status when treated with $\mathrm{NaCl}$.

\section{Materials and Methods}

\section{Plant material and culture conditions}

Barley (Hordeum vulgare cv. Tokak) seeds were provided by the Aegean Agricultural Research Institute and cultured as described previously (Temel and Gozukirmizi, 2012). Embryos were cultured in MS (Murashige and Skoog) medium supplemented with 0 (Control), 50 and $100 \mathrm{mM} \mathrm{NaCl}$, in a growth chamber (Sanyo). On the $20^{\text {th }}$ day, 10 seedlings were used for estimating the percentage of germination, maximum shoot and root length, and fresh weight.

\section{Estimation of total soluble protein levels and SOD activity}

Seedlings were crushed in 5 volumes of ice-cold phosphate buffer $(0.1 \mathrm{~mol} / \mathrm{L}, \mathrm{pH} 7.0)$ using a pre-chilled porcelain mortar and pestle. The homogenates were transferred into cold centrifuge tubes and centrifuged at $15,000 \mathrm{~g}$, at $4^{\circ} \mathrm{C}$ for $20 \mathrm{~min}$. The supernatants were used to estimate total soluble protein and SOD levels. The total soluble protein contents $(\mathrm{mg} / \mathrm{g})$ were estimated by a Bradford assay, using immunoglobulin (Sigma) as protein standard. SOD activity was measured spectrophotometrically, based on the inhibition of photochemical reduction of nitroblue tetrazolium (NBT) (Beauchamp and Fridovich, 1971). One $\mathrm{mL}$ reaction mixture contained $50 \mathrm{mmol} / \mathrm{L}$ phosphate buffer $(\mathrm{pH} 7.0), 50 \mathrm{mmol} / \mathrm{L}$ sodium carbonate, $0.1 \mathrm{mmol} / \mathrm{L}$ EDTA, 13 mmol l-methionine, $75 \mu \mathrm{mol} / \mathrm{L}$ NBT (Sigma), $2 \mu \mathrm{mol} / \mathrm{L}$ riboflavin and $2 \mu \mathrm{L}$ of $5 \mathrm{x}$ diluted plant extract. The samples were illuminated with three $15-\mathrm{W}$ white fluorescent lamps for $30 \mathrm{~min}$ at room temperature. An enzyme-free sample was used as positive control. One unit of SOD activity was defined as the amount of enzyme required to cause $50 \%$ inhibition of NBT reduction at $560 \mathrm{~nm}$. Enzyme activity was expressed as enzyme unit per $\mu \mathrm{g}$ protein per $\mathrm{min}(\mathrm{U} / \mu \mathrm{g}$ protein/min).

\section{Genomic DNA isolation}

Twenty-day-old seedlings were ground in liquid nitrogen and genomic DNAs (gDNA) were extracted (Tchorbadjieva and Pantchev, 2004). The gDNAs were resolved on $1 \%$ agarose gel in $1 \mathrm{x}$ TAE buffer, stained with ethidium bromide $(0.5 \mu \mathrm{g} / \mathrm{mL})$ and visualized under a UV transilluminator.

\section{RAPD analysis}

Sequences of five, 10-mer random primers (S1: CTACTGCGCT, S7: TCCGATGCTG, S10: ACCGTT CCAG, S13: GTCGTTCCTG, S19: GAGTCAGCAG) described elsewhere (Fernandez et al., 2002) were used; the primers were provided by SACEM (Turkey). The PCR mixture consisted of $1 \mathrm{x}$ buffer [ $80 \mathrm{mM}$ Tris- $\mathrm{HCl}, 20 \mathrm{mM}$ $\left(\mathrm{NH}_{4}\right)_{2} \mathrm{SO}_{4}, 0.02 \%$ Tween-20], $2.5 \mathrm{mM} \mathrm{MgCl} 2,0.25 \mathrm{mM}$ of each dNTP, $2 \mu \mathrm{M}(20 \mathrm{pmol})$ primer, $0.5 \mathrm{U}$ Taq polymerase (Solis BioDyne) and $10 \mathrm{ng}$ gDNA template in a $10 \mu \mathrm{L}$ reaction mixture. The amplification conditions were: an initial denaturation step of $5 \mathrm{~min}$ at $95^{\circ} \mathrm{C}, 40$ cycles of $60 \mathrm{~s}$ at $94^{\circ} \mathrm{C}, 60 \mathrm{~s}$ at $50^{\circ} \mathrm{C}$ and $90 \mathrm{~s}$ at $72^{\circ} \mathrm{C}$, and a final extension step of $10 \mathrm{~min}$ at $72^{\circ} \mathrm{C}$. The amplification products were resolved on $1.8 \%$ agarose gel in $1 \mathrm{x}$ TAE buffer at $70 \mathrm{~V} / \mathrm{cm}$, stained with ethidium bromide $(0.5 \mu \mathrm{g} / \mathrm{mL})$ and visualized under a UV transilluminator. Band sizes were determined by comparison with a 100 bp DNA ladder (Fermentas).

\section{CRED-RA analysis}

One $\mu \mathrm{g}$ gDNA samples were digested with $1 \mu \mathrm{L}$ (1 FDU) HpaII (FD0514, Fermentas) and $1 \mu \mathrm{L}$ (1 FDU) MspI (FD0544, Fermentas) according to the manufacturer's instructions, purified with a phenol:chloroform:isoamyl alcohol (25:24:1) solution, dissolved in $10 \mu \mathrm{L}$ of $10 \mathrm{mM}$ Tris- $\mathrm{HCl}(\mathrm{pH} 8.0)$ and used as template in CRED-RA. The primers used were S1 and S10. The CRED-RA mixture was the same as used for RAPD, except for the $3 \mu \mathrm{L}$ digestion product as template. A $3 \mu \mathrm{L}$ aliquot of the first PCR mixture was used as template in the second PCR assay. The amplification conditions were: an initial denaturation step of $5 \mathrm{~min}$ at $94^{\circ} \mathrm{C}, 40$ cycles of $60 \mathrm{~s}$ at $94^{\circ} \mathrm{C}, 60 \mathrm{~s}$ at $50^{\circ} \mathrm{C}$ and $90 \mathrm{~s}$ at $72^{\circ} \mathrm{C}$, and a final extension step of $5 \mathrm{~min}$ at $72^{\circ} \mathrm{C}$. The amplification products were resolved on $2 \%$ agarose gel in $1 \mathrm{x}$ TAE buffer at $70 \mathrm{~V} / \mathrm{cm}$, stained with ethidium bromide $(0.5 \mu \mathrm{g} / \mathrm{mL})$ and visualized under a UV transilluminator.

\section{Statistical analysis}

The physiological experiments were repeated three times independently and each data point is the arithmetic mean of triplicates $(n=3)$. Data were analyzed by OneWay Analysis of Variance (ANOVA), and the statistical significance of the difference between two groups was determined by the Least Significant Data (LSD) test. Molecular assays (RAPD, CRED-RA) were repeated twice with different genomic DNAs isolated from biological replicates.

\section{Results}

\section{Phenotypic and physiological analyses}

Mature embryos were cultured in 0 (control), 50 and $100 \mathrm{mM} \mathrm{NaCl}$-supplemented MS media for 20 days. All 
embryos germinated in the control and $50 \mathrm{mM}$ groups. However, the $100 \mathrm{mM} \mathrm{NaCl}$ concentration inhibited germination $(85.5 \%, \mathrm{p}<0.05)$. Salinity also caused physiological changes (Table 1). Both $\mathrm{NaCl}$ concentrations decreased the protein content $(p>0.05)$, fresh weight $(p<0.05)$ and shoot length $(p<0.05)$, while root growth $(p<0.05)$ was induced by $50 \mathrm{mM} \mathrm{NaCl}$. Both concentrations increased SOD activity $(\mathrm{p}<0.05)$. Decrease in fresh weight $[r(2)=(-0.99)$, $\mathrm{p}<0.01]$ and shoot length $[r(2)=(0.93), \mathrm{p}>0.05]$ and increase in SOD activity were dose-dependent: the higher concentration $(100 \mathrm{mM})$ inhibited root growth, while the lower concentration $(50 \mathrm{mM})$ stimulated it.

\section{Genetic and epigenetic analyses}

All five primers produced a total of 44 clear and reproducible bands. New bands were observed in salt-treated roots (Figures 1 and 2). The intensity of the same bands also increased in treated roots. No polymorphism was detected in shoot samples, in other words, the shoot DNA samples from different $\mathrm{NaCl}$ concentrations were monomorphic. The root and shoot RAPD patterns of the control group were different, but those of the $\mathrm{NaCl}$-treated groups were similar. gDNA samples of control and $\mathrm{NaCl}$-treated shoots were restricted with $H p a I I$ and $M s p I$ enzymes and then amplified using primers S1 and S10 (Figure 3).

A total of 21 bands were amplified, and five (23\%) of them represent methylation changes. Band type 1 (500 bp) was cut by HpaII only in the control DNA. HpaII was not able to cut this amplicon in treated plant DNA. Inner cytosine was methylated in the control group, but none of the cytosines were methylated in the treatment groups. Band type 1 represents a decrease in methylation by salt stress. Type 2 bands ( 250 and $650 \mathrm{bp}$ ) were cut by MspI but not by HpaII in the control group. Both enzymes failed to cut these

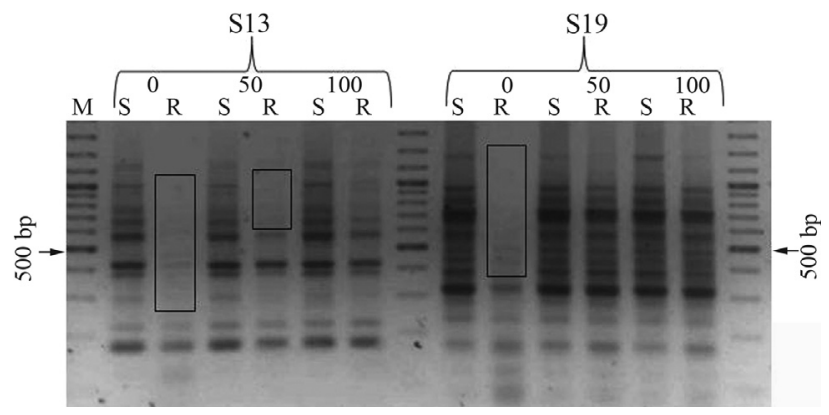

Figure 2 - RAPD results of primers S13 and S19. 0, 50 and 100 represent $\mathrm{NaCl}$ concentrations (mM). Polymorphic bands are indicated by rectangles.

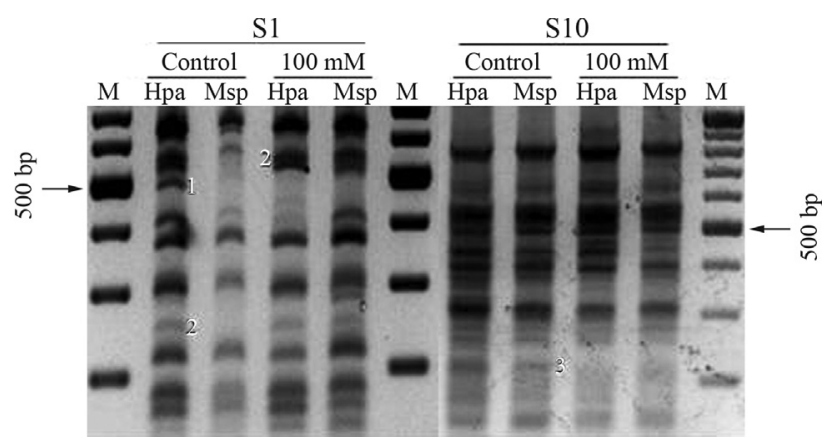

Figure 3 - CRED-RA results of primers $\mathrm{S} 1$ and $\mathrm{S} 10$ in $100 \mathrm{mM} \mathrm{NaCl}-$ -treated plants and controls. Polymorphic bands are indicated with numbers. Detailed interpretation can be found in the text.

Table 1 - Effects of salt stress on total soluble protein content, SOD activity, fresh weight, max shoot and root length.

\begin{tabular}{lccc}
\hline $\mathrm{NaCl}$ concentration $(\mathrm{mM})$ & 0 (control) & 50 & 100 \\
\hline Protein content (mg/g) & $51.28 \pm 13.9$ & $44.52 \pm 15$ & $39.12 \pm 8.83$ \\
SOD activity (U/mg protein.min) & $79.3 \pm 0.02 \mathrm{a}$ & $100.3 \pm 0.034 \mathrm{a}$ & $180.8 \pm 0.059 \mathrm{a}$ \\
Fresh weight (mg/plant) & $257 \pm 0.022 \mathrm{~b}$ & $203 \pm 0.007$ & $157 \pm 0.013 \mathrm{~b}$ \\
Max shoot length (mm) & $102.6 \pm 1.09 \mathrm{a}$ & $96 \pm 0.115 \mathrm{a}$ & $64.3 \pm 0.87 \mathrm{a}$ \\
Max root length (mm) & $30.1 \pm 0.36 \mathrm{a}$ & $44.5 \pm 0.6 \mathrm{a}$ & $22.7 \pm 0.39 \mathrm{a}$ \\
\hline
\end{tabular}

$\mathrm{a}=\mathrm{p}<0.01 ; \mathrm{b}=\mathrm{p}<0.05$ (LSD).

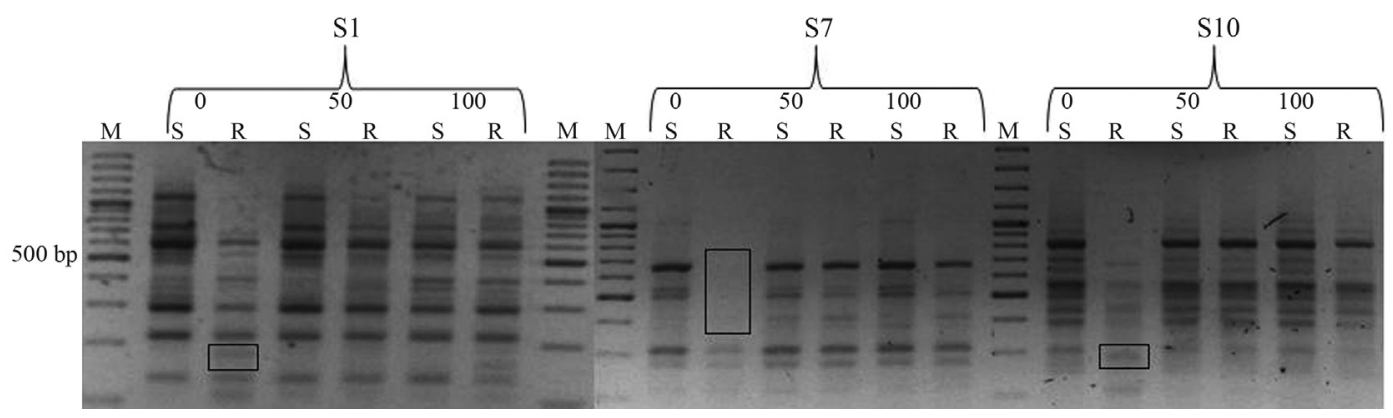

Figure 1 - RAPD results of primers S1, S7 and S10. 0, 50 and 100 represent $\mathrm{NaCl}$ concentrations (mM). Polymorphic bands are indicated by rectangles. 
amplicons in the treatment groups. Only inner cytosine was methylated in the control group, while both cytosines were methylated in the treatment groups. Type 2 bands represent an increase in methylation (inhibition of $M s p$ I digestion) by salt stress. Two bands, very close to each other and approximately 575 bp in size, were also marked as number 2 . Band type 3 (200 bp) may represent demethylation or mutation. Demethylation may have caused digestion and prevented amplification. Due to nucleotide variation, a recognition site may have occurred in the treated groups.

\section{Discussion}

Salt stress affects growth and germination (Anuradha and Rao, 2001). Root and shoot lengths and fresh weights of plants under salt stress are affected negatively, even at lower concentrations than the ones used in this study (Agarwal and Pandey, 2004). There are contradictory reports on protein content (Makela et al., 2000; Zhu et al., 2004) and SOD activity (Bor et al., 2003; Dionisio-Sese and Tobita, 2004) of plants under salt stress. In this study, the $50 \mathrm{mM}$ $\mathrm{NaCl}$ concentration did not cause a dramatic effect on growth and germination inhibition, while the $100 \mathrm{mM} \mathrm{NaCl}$ concentration did. In turn, root growth was induced at the $50 \mathrm{mM} \mathrm{NaCl}$ concentration. Protein content was decreased in both treatment groups. SOD activity was higher at both concentrations, especially at $100 \mathrm{mM} \mathrm{NaCl}$ that caused a dramatic increase. Tokak is also a drought-tolerant cultivar (Altinkut et al., 2001) and has been used in several studies on salt or drought tolerance (Ozturk et al., 2002). Salt stress also results in a water deficit condition in the plant, taking the form of a physiological drought (Mahajan and Tuteja, 2005). Therefore, we may postulate that Tokak is a salttolerant cultivar.

ROS are formed during salt stress and are harmful to macromolecules such as proteins, lipids and nucleic acids (Hernandez et al., 1993). Oxidative DNA damage can affect the DNA methylation patterns (Franco et al., 2008), and there are reports on salinity-induced DNA damage (Katsuhara and Kawasaki, 1996). However, this DNA damage was detected by agarose gel electrophoresis of DNA samples, which may fail to show less severe damage. Therefore, the use of molecular markers is crucial. Salt stress was reported to induce genetic modification (Guangyuan et al., 2007), and the effect of NaCl-induced DNA damage was dose-dependent. It was also shown that salinity alters DNA methylation in plants (Dyachenko et $a l .$, 2006). Salt stress-induced DNA methylation changes comprised both hypermethylation and hypomethylation events, but ended up leading to a net hypermethylation of the genome (Guangyuan et al., 2007). In the present study, the RAPD patterns of shoot samples were monomorphic, as were the shoots and roots of $\mathrm{NaCl}$-treated plants. However, some polymorphic bands were observed in roots of treated plants compared to controls. Fingerprinting patterns of shoots and roots of the control group were also altered. We propose that $\mathrm{NaCl}$ caused nucleotide variations and appearance of new bands in roots which were exposed to $\mathrm{NaCl}$ before the shoots. The DNA samples of shoots were not affected by salt stress. Most of the polymorphic CRED-RA bands represent methylation of both cytosines in the 5'CCGG3' sequence of $100 \mathrm{mM} \mathrm{NaCl}$-treated plants, allowing us to state that salt stress caused hypermethylation. However, the CRED-RA analysis was performed with shoot DNA samples only. There were two reasons for that: one was the low efficiency of DNA isolation from root samples, especially from treated ones, not yielding enough DNA for CRED-RA experiments. The second reason was the DNA polymorphism among root samples that does not allow to be sure whether the polymorphic CRED-RA bands are a result of DNA methylation or of DNA sequence variation.

In conclusion, although the biochemical and physiological effects of salinity were studied in detail, and mechanisms of salt stress and tolerance were reviewed exhaustively (Mahajan and Tuteja, 2005), there is still little information about the genetic and epigenetic effects of salinity in plants. We investigated here the physiological effects of salt stress at two $\mathrm{NaCl}$ concentrations (50 and $100 \mathrm{mM}$ ) in $H$. vulgare L. cv. Tokak, a drought-tolerant barley cultivar. The lower concentration of $\mathrm{NaCl}(50 \mathrm{mM})$ did not affect growth and germination dramatically, but interestingly favored root growth. DNA damage was observed only in roots, at both concentrations, and hypermethylation in shoots also occurred under salinity. Changes in methylation were observed when genetic variations were absent. This study may help understanding the relationship between cytosine methylation and salt tolerance.

\section{Acknowledgments}

This work was supported by the Research Fund of the Istanbul University (Project no: 21947). The authors are also grateful to the anonymous reviewers for their valuable suggestions.

\section{References}

Agarwal S and Pandey V (2004) Antioxidant enzyme responses to $\mathrm{NaCl}$ stress in Cassia angustifolia. Biol Plant 48:555-560.

Altinkut A, Kazan K, Ipekci Z and Gozukirmizi N (2001) Tolerance to paraquat is correlated with the traits associated with water stress tolerance in segregating F2 population of barley and wheat. Euphytica 121:81-86.

Anuradha S and Rao SSR (2001) Effect of brassinosteroids on salinity stress induced inhibition of seed germination and seedling growth of rice (Oryza sativa L.). Plant Growth Regul 33:151-153.

Bor M, Özdemir F and Türkan I (2003) The effect of salt stress on lipid peroxidation and antioxidants in leaves of sugar beet Beta vulgaris L. and wild Beet Beta maritima L. Plant Sci 164:77-84.

Causevic A, Delaunay A, Ounnar S, Righezza M, Delmotte F, Brignolas F, Hagege D and Maury S (2005) DNA methyl- 
ating and demethylating treatments modify phenotype and cell wall differentiation state in sugarbeet cell lines. Plant Physiol Biochem 43:681-691.

Dionisio-Sese M and Tobita S (2004) Antioxidant responses of rice seedlings to salinity stress. Plant Sci 135:1-9.

Dyachenko OV, Zakharchenko NS, Shevchuk TV, Bohnert HJ, Cushman JC and Buryanov YI (2006) Effect of hypermethylation of CCWGG sequences in DNA of Mesembryanthemum crystallinum plants on their adaptation to salt stress. Biochemistry (Moscow) 71:461-465.

El-Tayeb MA (2005) Response of barley grains to the interactive effect of salinity and salicylic acid. Plant Growth Regul 45:215-224.

Fernandez E, Figueiras M and Benito C (2002) The Use of ISSR and RAPD markers for detecting DNA polymorphism, genotype identification and genetic diversity among barley cultivars with known origin. Theor Appl Genet 104:845851.

Franco R, Schoneveld O, Georgakilas AG and Panayiotidis MI (2008) Oxidative stress, DNA methylation and carcinogenesis. Cancer Lett 266:6-11.

Guangyuan L, Xiaoming W, Biyun C, Gao G and Kun X (2007) Evaluation of genetic and epigenetic modification in rapeseed (Brassica napus) induced by salt stress. J Integr Plant Biol 49:1599-1607.

Hernandez JA, Corpas FJ, Gomez M, del Rio LA and Sevilla F (1993) Salt induced oxidative stress mediated by activated oxygen species in pea leaf mitochondria. Physiol Plant 89:103-110.

Imlay JA (2003) Pathways of oxidative damage. Annu Rev Microbiol 57:395-418.

Katsuhara M and Kawasaki T (1996) Salt stress induced nuclear and DNA degradation in meristematic cells of barley. Plant Cell Physiol 37:169-173.

Kirmizi S and Bell RW (2012) Responses of barley to hypoxia and salinity during seed germination, nutrient uptake, and early plant growth in solution culture. J Plant Nutr Soil Sci 175:630-640.

Kim SY, Lim JH, Park MR, Kim YJ, Park TI, Seo YW, Choi KG and Yun SJ (2005) Enhanced antioxidant enzymes are associated with reduced hydrogen peroxide in barley roots under saline stress. J Biochem Mol Biol 38:218-224.

Labra M, Ghiani A, Citterio S, Sgorbati S, Sala F, Vannini C, Ruffini-Castiglione M and Bracale M (2002) Analysis of cytosine methylation pattern in response to water deficit in pea root tips. Plant Biol 4:694-699.

Lewis J and Bird A (1991) DNA methylation and chromatin structure. FEBS Lett 285:155-159.

Lira-Medeiros CF, Parisod C, Fernandes RA, Mata CS, Cardoso MA and Ferreira PC (2010) Epigenetic variation in mangrove plants occurring in contrasting natural environment. PLos ONE 5:e10326.

Liu W, Li PJ, Qi XM, Zhou QX, Zheng L, Sun TH and Yang YS (2005) DNA changes in barley (Hordeum vulgare) seedlings induced by cadmium pollution using RAPD analysis. Chemosphere 61:158-167.

Lukens LN and Zhan SH (2007) The plant genome's methylation status and response to stress: Implications for plant improvement. Curr Opin Plant Biol 10:317-322.

Mahajan S and Tuteja N (2005) Cold, salinity and drought stresses: An overview. Arch Biochem Biophys 444:139-158.

Makela P, Karkkainen J and Somersalo S (2000) Effect of glycinebetaine on chloroplast ultrastructure, chlorophyll and protein content, and RuBPCO activities in tomato grown under drought or salinity. Biol Plant 43:471-475.

Mian A, Oomen RJ, Isayenkov S, Sentenac H, Maathuis FJ and Very AA (2011) Over-expression of an $\mathrm{Na}+$ and $\mathrm{K}+$ permeable HKT transporter in barley improves salt tolerance. Plant J 68:468-479.

Ozturk ZN, Talame V, Deyholos M, Michalowski CB, Galbraith DW, Gozukirmizi N, Tuberosa R and Bohnert HJ (2002) Monitoring large-scale changes in transcript abundance in drought- and salt-stressed barley. Plant Mol Biol 48:551573.

Samal KC, Jena RC, Swain SS, Das BK and Chand PK (2012) Evaluation of genetic diversity among commercial cultivars, hybrids and local mango (Mangifera indica L.) genotypes of India using cumulative RAPD and ISSR markers. Euphytica 185:195-213.

Tan MP (2010) Analysis of DNA methylation of maize in response to osmotic and salt stress based on methylationsensitive amplified polymorphism. Plant Physiol Biochem 48:21-26.

Tchorbadjieva MI and Pantchev IY (2004) DNA methylation and somatic embryogenesis of orchardgrass (Dactylis glomerata L.). Bulg J Plant Physiol 30:3-13.

Temel A and Gozukirmizi N (2012) Effects of homobrassinolide in barley callus culture. Plant Soil Environ 58:441-445.

Uthup TK, Ravindran M, Bini K and Thakurdas S (2011) Divergent DNA methylation patterns associated with abiotic stress in Hevea brasiliensis. Mol Plant 4:996-1013.

Weitzman SA, Turk PW, Milkowski DH and Kozlowski K (1994) Free radical adducts induce alterations in DNA cytosine methylation. Proc Natl Acad Sci USA 91:1261-1264.

Zhu Z, Wei G, Li J, Qian Q and Yu J (2004) Silicon alleviates salt stress and increases antioxidant enzymes activity in leaves of salt-stressed cucumber (Cucumis sativus L.). Plant Sci $167: 527-533$

\section{Internet Resources}

FAO (1992) The use of saline waters for crop production, http://www.fao.org/docrep/T0667E/T0667E00.htm (August 30, 2012).

Associate Editor: Adriana S. Hemerly

License information: This is an open-access article distributed under the terms of the Creative Commons Attribution License, which permits unrestricted use, distribution, and reproduction in any medium, provided the original work is properly cited. 